\title{
Air quality assessment in different urban areas from Rio Grande do Sul state, Brazil, using lichen transplants
}

\author{
NATÁLIA MOSSMANN KOCH ${ }^{1,2}$, FABIANE LUCHETA ${ }^{3}$, MÁRCIA ISABEL KÄFFER ${ }^{3}$, \\ SUZANA MARIA DE AZEVEDO MARTINS ${ }^{4}$ and VERA MARIA FERRÃO VARGAS ${ }^{1}$
}

\author{
${ }^{1}$ Graduate Program in Ecology, Universidade Federal do Rio Grande do Sul, Av. \\ Bento Gonçalves, 9500, 90650-001 Porto Alegre, RS, Brazil \\ ${ }^{2}$ Graduate Program in Vegetation Biology, Universidade Federal de Mato Grosso do \\ Sul, Av. Costa e Silva, s/n, 79070-900 Campo Grande, MS, Brazil \\ ${ }^{3}$ Graduate Program in Environmental Sciences, Botany Laboratory, Universidade Feevale, \\ Rodovia ERS 239, 2755, 93525-075 Novo Hamburgo, RS, Brazil \\ ${ }^{4}$ Botany Department, Fundação Zoobotânica do Rio Grande do Sul, R. Dr. Salvador \\ França, 1427, Jardim Botânico, 90690-000 Porto Alegre, RS, Brazil
}

Manuscript received on December 4, 2017; accepted for publication on January 19, 2018

\begin{abstract}
Based on the need to monitor air pollution and on the importance of doing it with biological organisms, the present work had as main objective to assess air quality in urban areas through lichen transplants. Besides, we also tested whether there were differences among the studied sites, aiming to point out the main pollution characteristics of the areas. The monitoring was carried out in seven cities, which varied from mainly rural to mainly industrial, in Rio Grande do Sul, southern Brazil. The foliose lichen Parmotrema tinctorum was used as the biomonitor species. Physiological tests and contents of sulphur and heavy metals were measured in the lichen thalli. Other pollutants assessed through air samplers were available for some cities, and modeled concentrations of fine particulate matter and nitrogen oxides for all sites. The effect of air pollution negatively reflected on the physiology parameters of the lichen and the concentration of all heavy metals increased after exposure, especially in the industrial sites. We generated a profile of air pollutants and pointed out that Charqueadas and Esteio had the worst air quality. Since they have high demographic densities, the results are of great public health concern and could be guidelines for future studies.
\end{abstract}

Key words: air pollution, biomonitoring, greenhouse gases, heavy metals, lichenized fungi, particulate matter.

Correspondence to: Natália Mossmann Koch

E-mail: natimkoch@ymail.com

* Contribution to the centenary of the Brazilian Academy of

Sciences. 


\section{INTRODUCTION}

Air pollution from industrial biomass and fossil fuel burning can spread far beyond the limits of the country that generated it (Akimoto 2003). Globally spread, these emissions are changing the world climate. According to the latest report of the IPCC (Intergovernmental Panel on Climate Change) (Pachauri et al. 2014) recent anthropogenic emissions of greenhouse gases are the highest in history and together with other anthropogenic drivers (such as heavy metals or organic compounds), are extremely likely to have been the dominant cause of the observed warming. In addition to climate change, environmental pollution is also one of the greatest concerns in public health (Cansaran-Duman et al. 2010). Recently the World Health Organization (WHO) called attention to the great impact of air pollution on children's health and mortality worldwide (WHO 2017).

It is very important to adopt local actions to control and monitor air quality, not only at the regional scale of population health, but also considering the global impact of air pollution. The use of biological monitors such as trees (Domingos et al. 2015, Alves et al. 2001), grasses (Crittenden and Read 1979, Sandrin et al. 2013), mosses (Bignal et al. 2008, Gerdol et al. 2014) or lichens (Carreras and Pignata 2002, Loppi and Frati 2006, Riddell et al. 2012) have proven to be efficient. Here we will focus on lichens, which are long considered good tools to monitor air pollution and air quality (Hawksworth et al. 2005).

The use of lichens for monitoring atmospheric pollution is known since independent observations made in England, Munich and Paris in the 1800s documented that these organisms were disappearing from urban areas (Nash III 2008). So far, many studies had shown and proved that lichens are indeed good biomonitors and bioindicators of air pollution of different kinds and origins (Conti and
Cecchetti 2001, Käffer et al. 2012, Pinho et al. 2011).

One of the possible ways to monitor air pollution with lichens is the active monitoring method. It consists on the exposure of a welldefined biomonitor species under relatively controlled conditions (Szczepaniak and Biziuk 2003). This strategy allows an immediate and accessible evaluation, which is convenient where there is no other way to measure the atmospheric pollution (Aras et al. 2011), as is the case with most developing countries.

Because of the constant need to monitor air pollution and the importance of using biological organisms, our work had as main objective to assess air quality in urban areas with industrial and rural influences. We looked at changes in lichen biology: 1) pollution absorbed by the biomonitor species; 2) physiological damages observed on the thalli; and used other biomonitoring tools: 3) automatic/ semi-automatic air samplers of pollutants and 4) pollution data models for the areas. We also compared cities to characterize the main pollutants of each site.

\section{MATERIALS AND METHODS}

\section{STUDY AREA}

The atmospheric monitoring was carried out in seven cities: Esteio(ES), Triunfo(TR), Charqueadas $(\mathrm{CH})$, Montenegro (MO), Santo Antônio da Patrulha (SA), Caraá (CA) and Maquiné (MA), all located in the northeastern region of the state of Rio Grande do Sul, southern Brazil (Figure 1).

These cities have great importance for the state economy hosting many industries (Esteio, Charqueadas and Montenegro), a Petrochemical Complex (Triunfo), and an important agricultural area of family farming (Santo Antônio da Patrulha, Maquiné and Caraá). A description of the main industrial activities, the demographic density and the rural practices of the monitored 


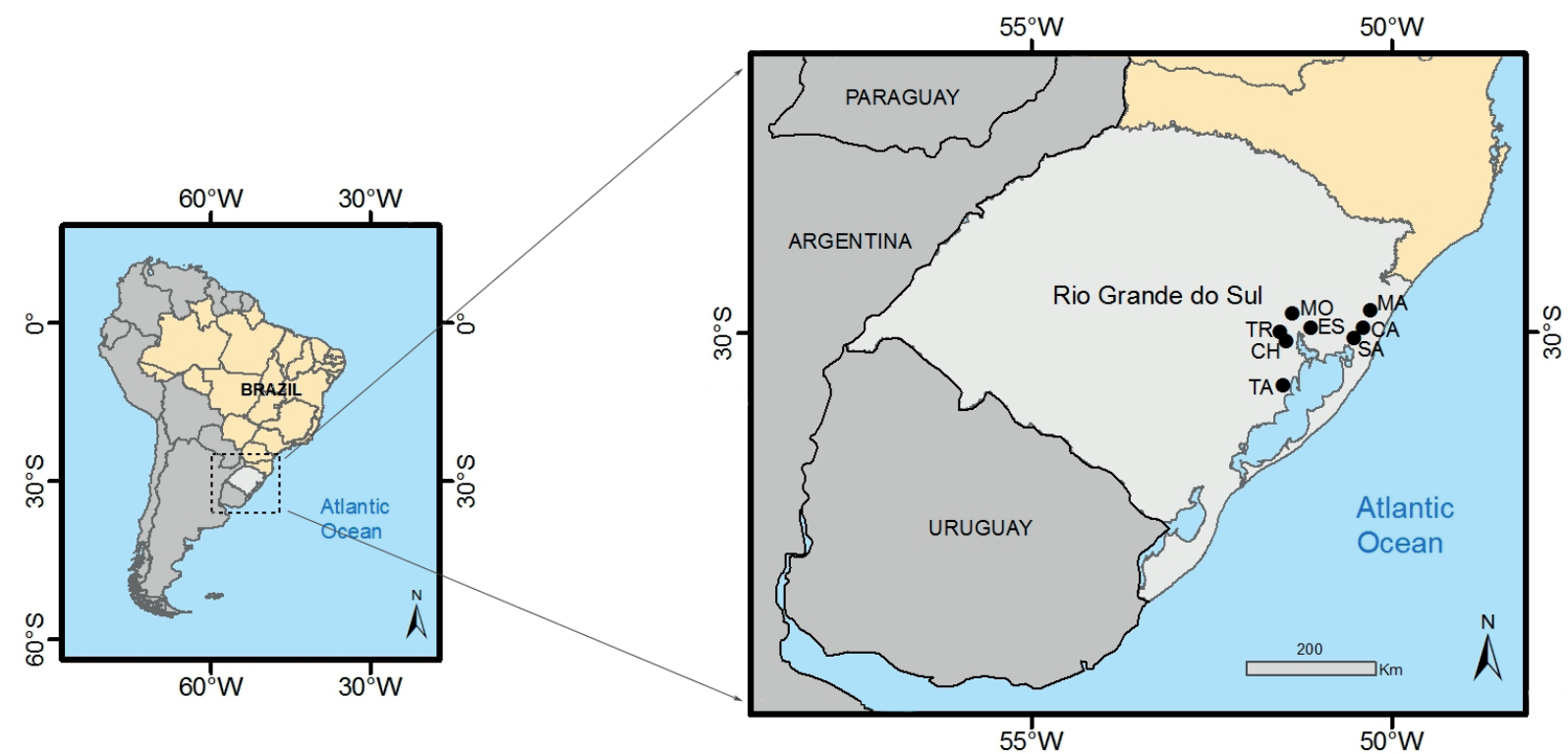

Figure 1 - Location of the seven monitored cities (CA, MA, SA, CH, TR, ES and MO) and the city where lichen samples of Parmotrema tinctorum were collected (TA) to be later exposed to monitor air pollution. Abbreviations: $\mathrm{CA}=\mathrm{Caraá}$; $\mathrm{MA}=$ Maquiné; $\mathrm{SA}=$ Santo Antônio da Patrulha; $\mathrm{CH}=$ Charqueadas; $\mathrm{TR}=$ Triunfo; $\mathrm{ES}=$ Esteio; $\mathrm{MO}=$ Montenegro; $\mathrm{TA}=$ Tapes.

cities are detailed in Koch et al. (2016). They also have a similar climate, elevation, and some of them (Charqueadas, Esteio and Santo Antônio da Patrulha) have air-monitoring systems with automatic and semi-automatic air samplers. The elevation of sampling areas ranges from 10 to 75 $\mathrm{m}$ above sea level and the climate is subtropical humid, Cfa type according to the updated KöppenGeiger classification (Peel et al. 2007).

\section{SAMPLE PREPARATION AND LICHEN EXPOSURE TREATMENTS}

The foliose epiphytic lichen Parmotrema tinctorum (Despr. ex Nyl.) Hale was chosen as the biomonitor species. This species has a known tolerance to air pollution, having been used in other monitoring studies in southern Brazil (Käffer et al. 2012) and is abundant throughout the country (Spielmann and Marcelli 2009). The lichen P. tinctorum is naturally found in all the studied cities, but we chose to transplant the thalli from a less polluted site to standardize the exposure and due to its low abundance in some sites. Samples of $P$. tinctorum were collected mainly on trunks of planted Eucalyptus spp. in Tapes (Figure 1) to be later transplanted into potentially polluted sites. The municipality of Tapes is located at least 80 $\mathrm{km}$ distant from large urban centers and thus far from important sources of air pollution, being agriculture and cattle raising the main economic sources of the region. Before being exposed, the thalli of $P$. tinctorum were left in the laboratory for acclimation during ten days (Käffer et al. 2012).

Lichens were placed in $55 \times 35 \mathrm{~cm}$ synthetic nettings in standardized structures ca. $120 \mathrm{~cm}$ from the ground and shaded to reduce sunlight exposure (Figure 2). They were placed vertically, which was the same position they were found on the trees. When available, lichen transplants were set close to existing automatic/semi-automatic air samplers. Before exposing the samples of $P$. tinctorum, we performed chemical control analyses to test for metal and sulphur contents. Prior physiological damages were also assessed in some samples of these thalli. 

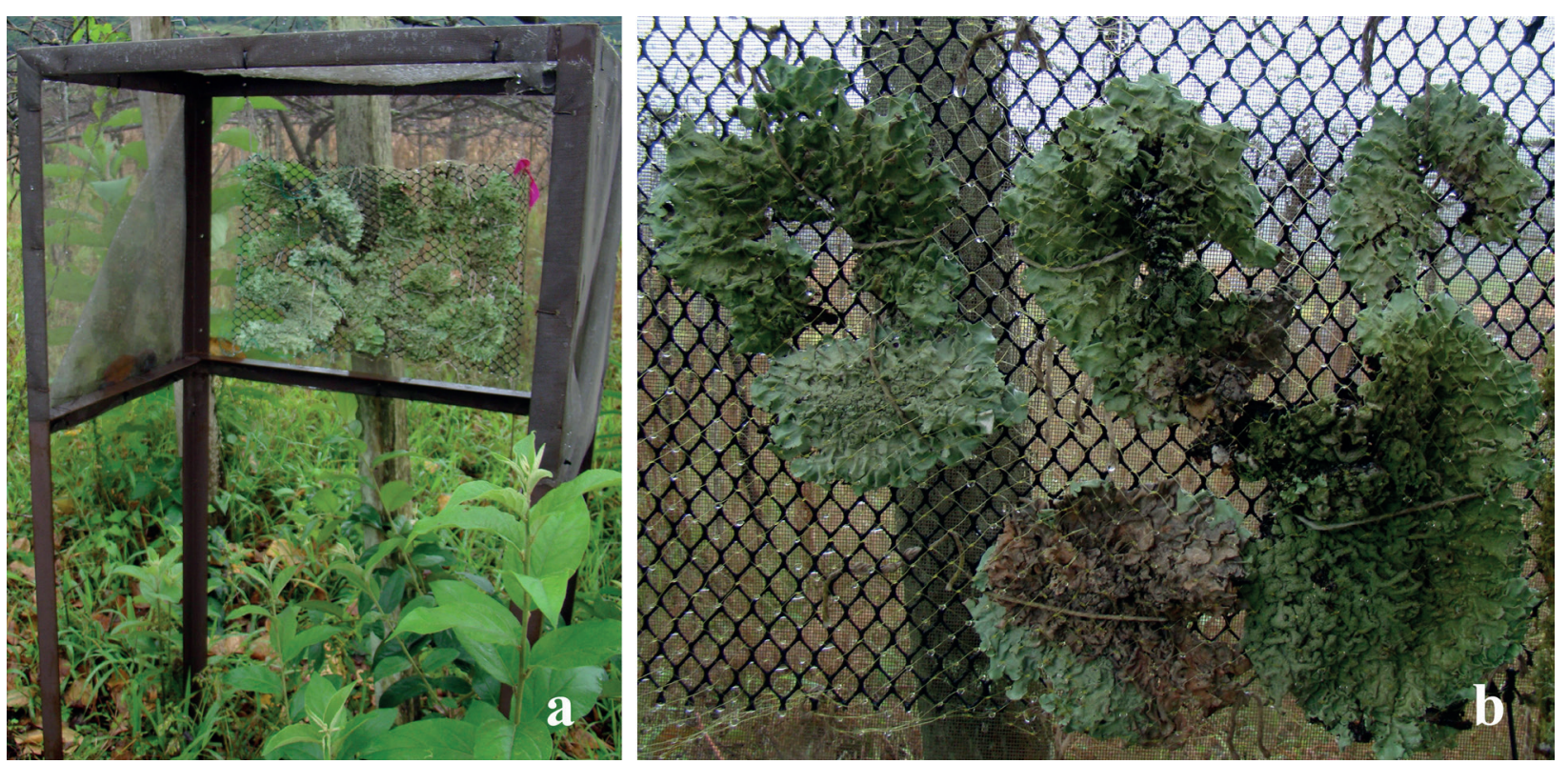

Figure 2 - a. Thalli of Parmotrema tinctorum exposed in the standardized structures. b. Detail of P. tinctorum in the synthetic nettings after three months of exposure.

Transplants were exposed from March to October 2013 and from April to November 2014. Sub-samples of these materials were taken after two, five and seven months of exposure, in all seven cities monitored, in both years. We gathered data for 14 months and six sub-samples in each city. Maquiné and Caraá were the control sites, based on the characteristics of low urbanization and the absence of large industries in these municipalities. Maquiné was only monitored in 2014, after Caraá, supposed to have lower air pollution, showed some important pollutants concentration in 2013.

\section{PHYSIOLOGICAL ANALYSES}

Each of the six lichen sub-samples were tested for physiological responses to atmospheric pollution, and analyzed prior to exposure, for control. All pieces of bark were removed and the lichen thalli were cleaned with a brush. Part of the thalli was macerated and the percentages of live, dead and plasmolysed algal cells were counted under the microscope using the neutral-red test at 5\% (Le Blanc 1971, Calvelo and Liberatore 2004). With the same macerate samples we analyzed
Chlorophyll $a$ and $b$ according to the method proposed by Boonpragob (2002), which consisted of test tubes with $10 \mathrm{~mL}$ of $96 \%$ ethanol and $5 \mathrm{~cm}^{2}$ of lichens. Absorbance in the wavelengths of 649 and $665 \mathrm{~nm}$ was measured with spectrophotometer Digimed DME-21. Chlorophyll contents and the percentage of live, dead and plasmolysed algal cells are methods for analyzing physiological damages on the lichen photobiont. Organic carbon content, which measures physiological damage on the lichen mycobiont, was analyzed through wet combustion using the Walkley-Black method with external heat (APHA 2005), on the Laboratory of Soil Analyses at Universidade Federal do Rio Grande do Sul.

\section{CHEMICAL ANALYSES}

We tested total content of the following pollutants in the lichen thalli: sulphur $(\mathrm{S})$, copper $(\mathrm{Cu})$, zinc $(\mathrm{Zn})$, iron $(\mathrm{Fe})$, manganese $(\mathrm{Mn})$, chromium $(\mathrm{Cr})$, nickel $(\mathrm{Ni})$, lead $(\mathrm{Pb})$, vanadium $(\mathrm{V})$ and aluminum (Al). Analyses were made through inductively coupled plasma optical emission spectrometry 
(ICP-OES) (Boss and Fredeen 2004) with previous acid digestion. Samples were dried before being macerated. Chemical analyses were made in the Laboratory of SoilAnalyses at Universidade Federal do Rio Grande do Sul and were validated with the use of spikes and the certified reference material SRM 1515, for Apple Leaves and Domestic Sludge SRM 2781.

\section{OTHER POLLUTION VARIABLES}

Other pollution variables were available for some of the monitored sites, such as particulate matter $\left(\mathrm{PM}_{10}\right)$, sulphur dioxide $\left(\mathrm{SO}_{2}\right)$, ozone $\left(\mathrm{O}_{3}\right)$, carbon monoxide $(\mathrm{CO})$ and nitrogen dioxide $\left(\mathrm{NO}_{2}\right)$. These data were obtained through automatic samplers in Charqueadas and Esteio and semi-automatic air samplers in Santo Antônio da Patrulha. Samplers belonged to the Environmental Department of the State of Rio Grande do Sul (FEPAM - Fundação Estadual de Proteção Ambiental Henrique Luiz Roessler), but in some cases data were not available for all the monitoring period and did not include all parameters $\left(\mathrm{PM}_{10}, \mathrm{SO}_{2}, \mathrm{O}_{3}, \mathrm{CO}\right.$ and $\left.\mathrm{NO}_{2}\right)$. Sample data were compared with the standards of air quality in Brazil (CONAMA 1990) and with the guidelines of World Health Organization (WHO 1999, 2006).

We also assessed modeled atmospheric concentrations of $\mathrm{NO}_{\mathrm{x}}$ and $\mathrm{PM}_{2.5}$, from the Chemistry Coupled Aerosol-Tracer Transport Modeling System (CCATT-BRAMS, Freitas et al. 2009, Longo et al. 2013), for each study site. Data were provided by the Group of Modeling of the Atmosphere and its Interfaces from Universidade Federal de Pelotas, state of Rio Grande do Sul (http://ccatt.ufpel.edu.br). Because the model had been recently implemented on the state, data were only available for 2014 on.

\section{STATISTICAL ANALYSES}

Aiming to test whether monitored sites (i.e. seven cities) differed according to air quality, we performed a PCA (Principal Component Analysis) using a matrix of the sites described by metals, sulphur and modeled pollutants. The result scores were plotted in a biplot and variables scores were scaled by the square root of eigenvalues. This analysis was made with the "rda" function of CRAN software R using package Vegan (R Core Team 2015).

\section{RESULTS}

\section{LICHEN PHYSIOLOGICAL RESPONSES}

Overall, monitored sites had only slight differences regarding physiological damages on the thalli of Parmotrema tinctorum. The organic carbon contents (OC) after exposure did not show any clear differences among cities, and neither did the chlorophyll contents (Table I). Regarding the percentage of algal live cells, Triunfo (TR) was the site with the lowest values at the end of the exposure period in 2013 and 2014 (29.8\% and $10.4 \%$, respectively), while Montenegro (MO) showed the highest values after seven months of exposure in 2013 (46.1\%). The highest values for Maquiné (MA) and Charqueadas (CH) were in 2014 (both around 46\%). This parameter also showed a decrease in almost all sites after exposure, with the exception of MA and MO in 2014 (Table I). The percentage of dead algal cells in 2013 had a similar, but opposite, pattern to the live cells. However, the same did not happen in 2014, when the highest values in seven months were found in Esteio (ES) and the lowest in TR, the latter showing also an expressive higher value of plasmolysed algal cells in 2014 (59.8\%) (Table I). 
TABLE I

Lichen physiological parameters measured to evaluate the damages on the photobiont $(\mathrm{Chl} a, \mathrm{Chl} b$ and percentage of live, plasmolysed and dead cells) and on the mycobiont (percentage of organic carbon) after exposure. Thalli of Parmotrema tinctorum were exposed during seven months in 2013 and 2014.

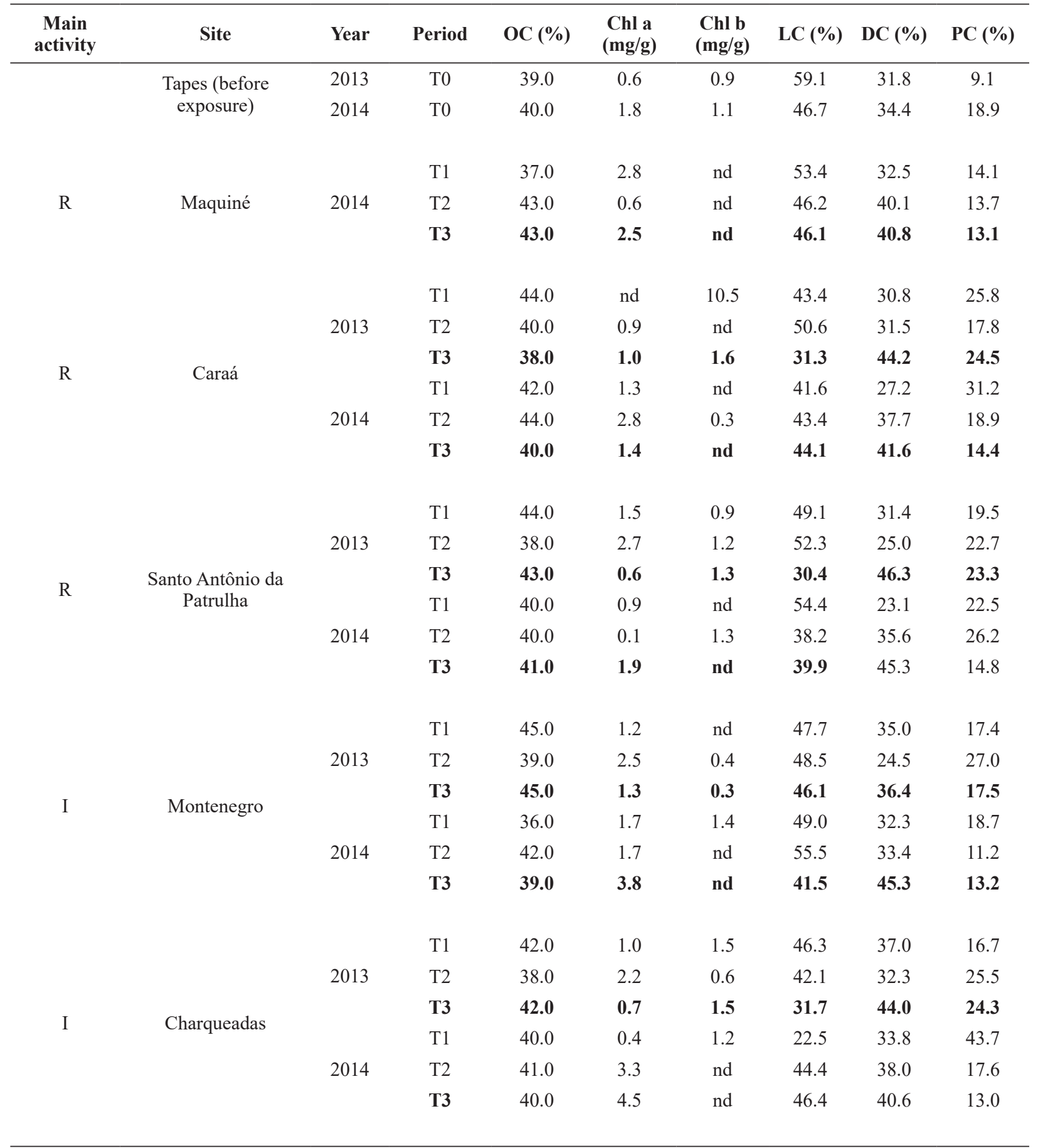


TABLE I (continuation)

\begin{tabular}{|c|c|c|c|c|c|c|c|c|c|}
\hline $\begin{array}{c}\text { Main } \\
\text { activity }\end{array}$ & Site & Year & Period & OC (\%) & $\begin{array}{c}\text { Chl a } \\
(\mathrm{mg} / \mathrm{g})\end{array}$ & $\begin{array}{c}\text { Chl b } \\
(\mathrm{mg} / \mathrm{g})\end{array}$ & LC (\%) & DC (\%) & PC (\%) \\
\hline \multirow{6}{*}{ I } & \multirow{6}{*}{ Esteio } & & $\mathrm{T} 1$ & 43.0 & 3.4 & nd & 41.5 & 38.1 & 20.3 \\
\hline & & 2013 & $\mathrm{~T} 2$ & 36.0 & 2.0 & nd & 33.4 & 35.1 & 31.6 \\
\hline & & & T3 & 43.0 & 0.6 & 1.2 & 32.8 & 43.8 & 23.4 \\
\hline & & & $\mathrm{T} 1$ & 40.0 & 1.2 & nd & 34.9 & 35.7 & 29.4 \\
\hline & & 2014 & $\mathrm{~T} 2$ & 42.0 & 3.6 & nd & 28.0 & 44.2 & 27.8 \\
\hline & & & T3 & 40.0 & 4.7 & nd & 25.9 & 53.8 & 20.2 \\
\hline \multirow{6}{*}{ I } & \multirow{6}{*}{ Triunfo } & & $\mathrm{T} 1$ & 42.0 & 1.9 & 1.7 & 51.2 & 34.1 & 14.7 \\
\hline & & 2013 & $\mathrm{~T} 2$ & 40.0 & nd & 7.7 & 42.9 & 32.9 & 24.1 \\
\hline & & & T3 & 42.0 & 2.0 & 1.4 & 29.8 & 47.5 & 22.7 \\
\hline & & & $\mathrm{T} 1$ & 37.0 & 7.9 & nd & 37.4 & 42.0 & 20.5 \\
\hline & & 2014 & $\mathrm{~T} 2$ & 43.0 & 1.8 & 0.3 & 37.3 & 46.9 & 15.8 \\
\hline & & & T3 & 42.0 & 6.8 & nd & 10.4 & 29.8 & 59.8 \\
\hline
\end{tabular}

*Abbreviations: $\mathrm{OC}=$ Organic Carbon; LC = Live Cells; DC = Dead Cells; PC = Plasmolysed Cells; R = Rural; I = Industrial; $\mathrm{TA}=$ Tapes; b.e. $=$ before exposure; $\mathrm{MA}=$ Maquiné; $\mathrm{CA}=$ Caraá; $\mathrm{SA}=$ Santo Antônio da Patrulha; $\mathrm{MO}=\mathrm{Montenegro}$; $\mathrm{CH}=$ Charqueadas; $\mathrm{ES}=$ Esteio; $\mathrm{TR}=$ Triunfo; $\mathrm{nd}=$ not detected; $\mathrm{T} 0=$ contents prior to exposure; $\mathrm{T} 1=$ after two months; $\mathrm{T} 2=$ after five months; T3 = after seven months

\section{AIR POLLUTANTS MONITORING}

Most air pollutants analyzed with the lichen biomonitor, the air samplers and the modeled data had different concentrations in industrial and rural cities (Table II, Figures 3 and 4).

Regarding the metals absorbed by the lichen $P$. tinctorum, differences were found especially in the concentration of copper, zinc, iron, chromium and nickel, with higher values in $\mathrm{CH}$ and $\mathrm{MO}$ in general. There was no clear difference among sites for the other heavy metals and sulphur contents. However, when comparing these values with the ones before exposure, in the control sample, we observed that almost all pollutants were more concentrated after the exposure period (Figure 3).

High contents of pollutants were even found in the rural areas (CA, MA and SA): suplhur, zinc, chromium, nickel, lead, vanadium and aluminum had similar or higher concentrations than those found in some industrial sites (Figure 3). It is important to note that chromium had a considerable peak in CA and SA in 2013 (more than $160 \mathrm{mg}$ / $\mathrm{kg}$ ), which did not repeat in 2014. Moreover, sulphur peaked at the beginning of 2014, reaching all sampled cities. At the industrial sites (MO, TR, $\mathrm{CH}$ and ES) all pollutants increased after exposure when compared to the control (Figure 3).

Data from the air samplers were not available for all monitored cities during the seven months when the lichens were exposed (2013 and 2014). However, based on the available data we found differences among some cities (Table II). The modeled contents of $\mathrm{NO}_{\mathrm{x}}$ and $\mathrm{PM}_{2.5}$ (Figure 4) also varied among cities, being higher in $\mathrm{ES}$ and $\mathrm{CH}$, both industrial cities.

$\mathrm{CH}$ had higher values of $\mathrm{PM}_{10}$ than $\mathrm{SA}$, similar to the modeled $\mathrm{PM}_{2.5}$, where even higher values were found for ES (Figure 4). Particulate matter in $\mathrm{CH}$ also exceeded the recommended values for health security in both periods evaluated (WHO 2006) (Table II). Measured contents of $\mathrm{SO}_{2}$, showed differences among $\mathrm{CH}$, ES and SA, with Charqueadas $(\mathrm{CH})$ showing higher concentrations than Esteio (ES) and Santo Antônio da Patrulha 

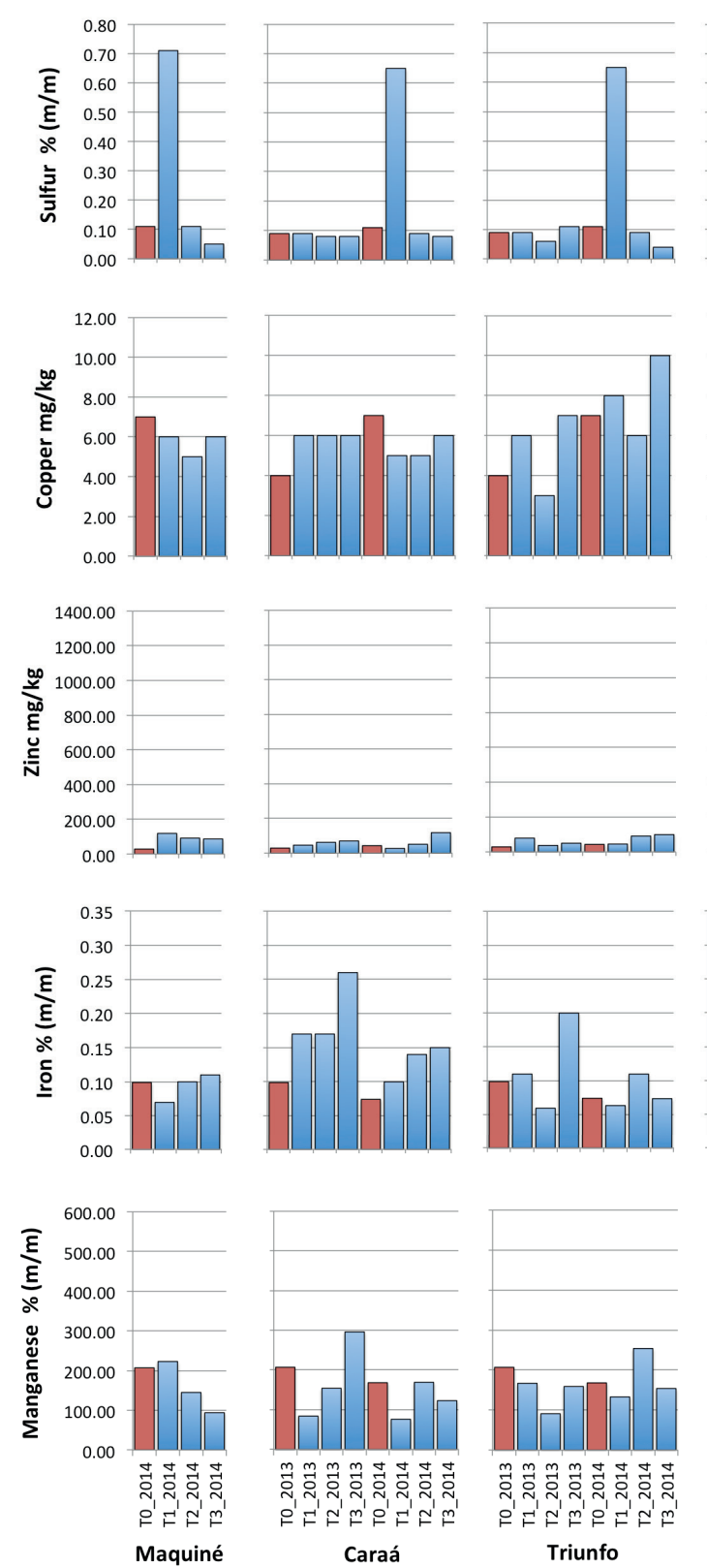
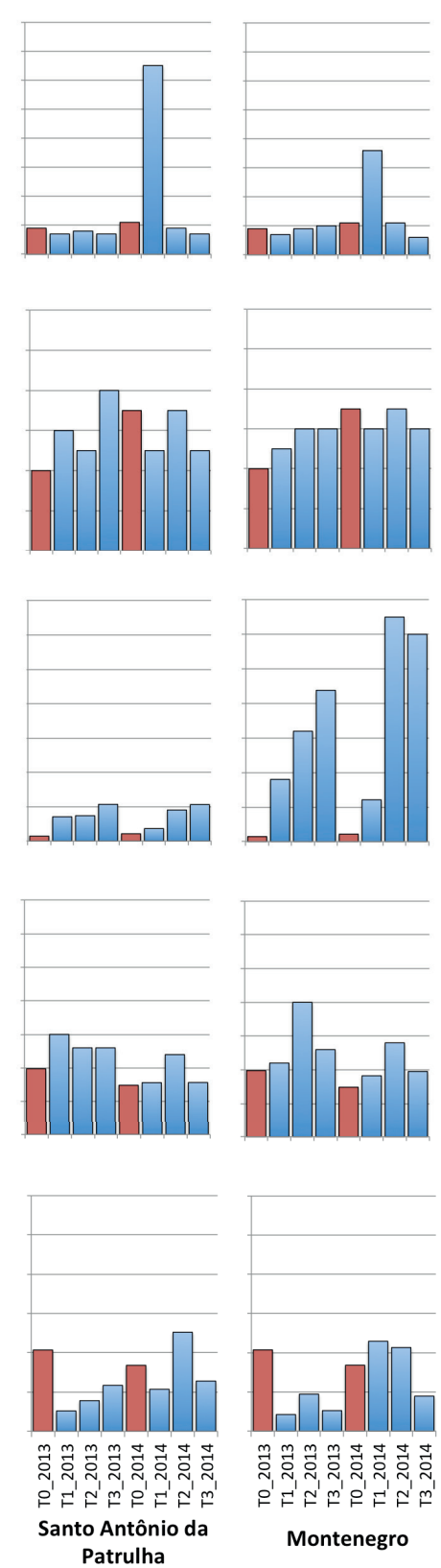
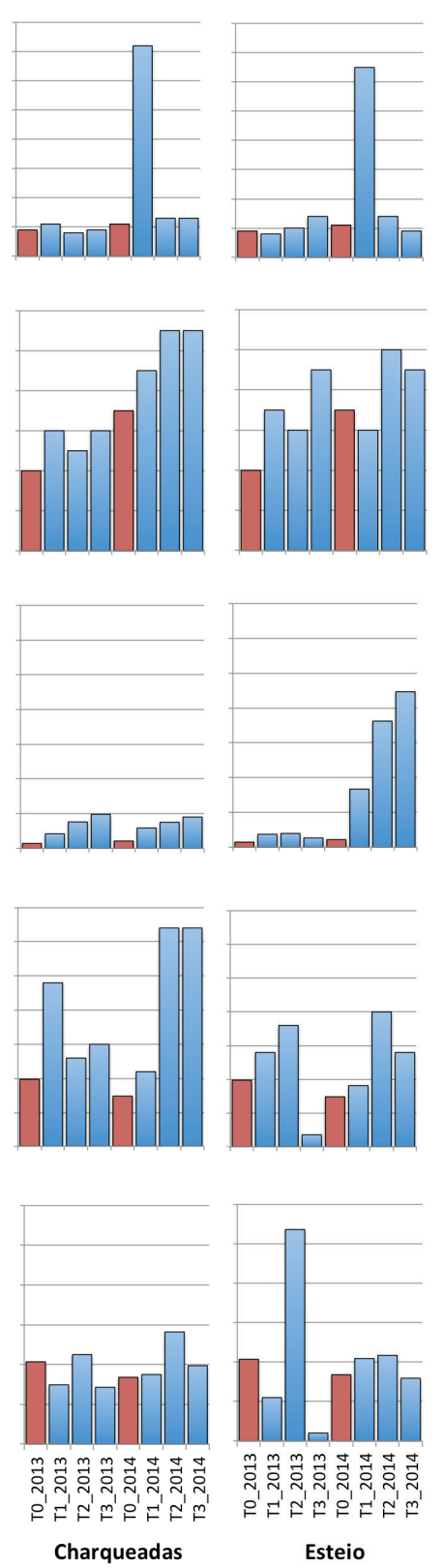

Figure 3 - Contents of sulphur and metals absorbed by the lichen Parmotrema tinctorum during seven months of exposure in 2013 and 2014. The red column represents the basal values, prior to exposure in the cities. $\mathrm{T} 0=$ contents prior to exposure; $\mathrm{T} 1=$ after two months; T2 = after five months; T3 = after seven months. 

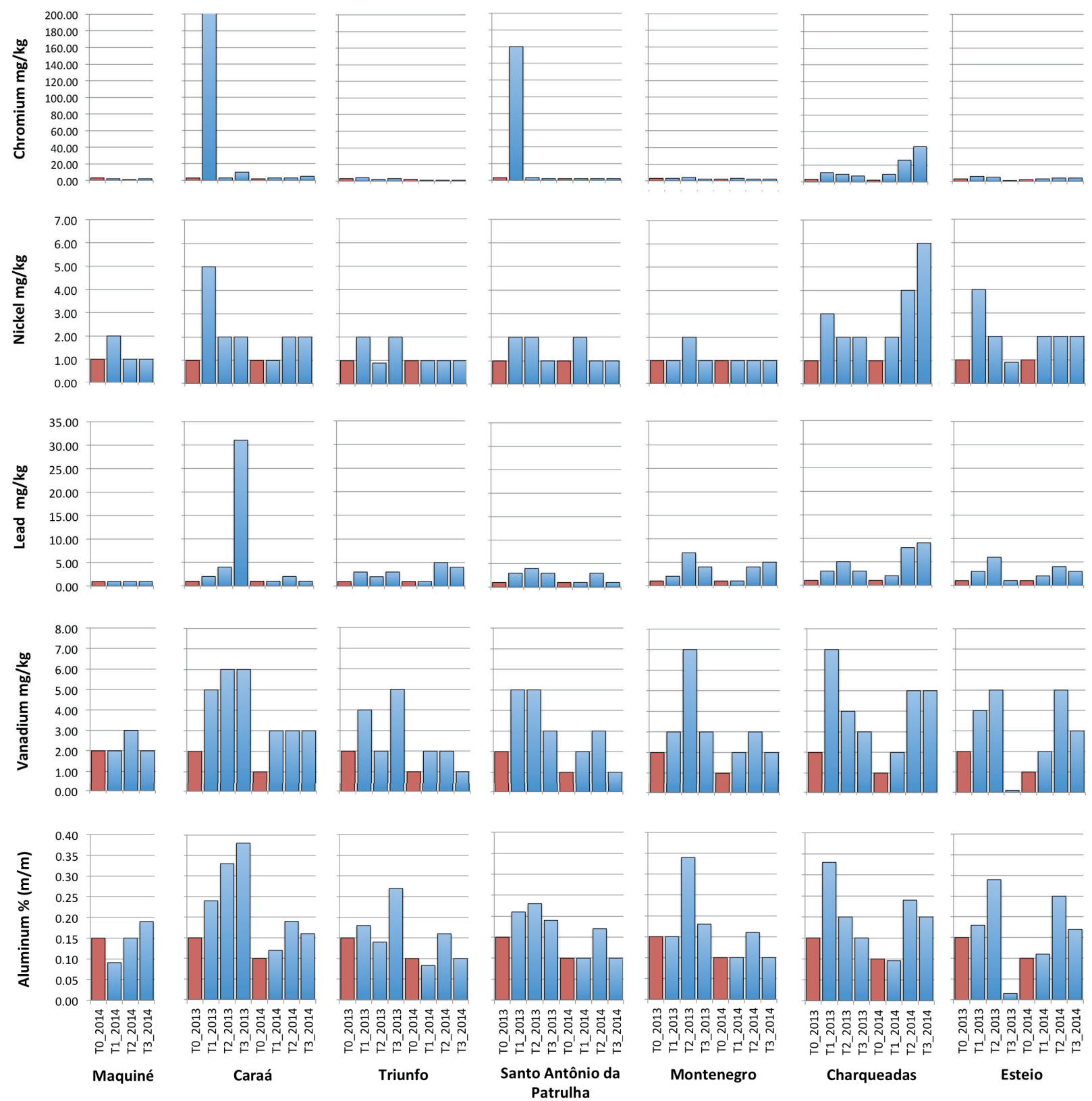

Figure 3 (continuation)- Contents of sulphur and metals absorbed by the lichen Parmotrema tinctorum during seven months of exposure in 2013 and 2014. The red column represents the basal values, prior to exposure in the cities. T0 = contents prior to exposure; $\mathrm{T} 1$ = after two months; $\mathrm{T} 2=$ after five months; $\mathrm{T} 3=$ after seven months. 
TABLE II

Means and standard deviations for $\mathrm{PM}_{10}$ and the greenhouse gases that were sampled by the automatic and the semi-automatic air samplers in 2013 and 2014.

\begin{tabular}{|c|c|c|c|c|c|c|c|}
\hline City & $\begin{array}{l}\text { Type of } \\
\text { sampler }\end{array}$ & $\begin{array}{l}\text { Measuring } \\
\text { period }\end{array}$ & $P M_{10}\left(\mu \mathrm{g} / \mathrm{m}^{3}\right)$ & $\mathrm{SO}_{2}\left(\mu \mathrm{g} / \mathrm{m}^{3}\right)$ & $\mathrm{NO}_{2}\left(\mu \mathrm{g} / \mathrm{m}^{3}\right)$ & $O_{3}\left(\mu \mathrm{g} / \mathrm{m}^{3}\right)$ & $\mathrm{CO}(\mathrm{ppm})$ \\
\hline \multirow{2}{*}{ Charqueadas } & \multirow{2}{*}{ Automatic } & 2013 & $33.7 \pm 0.6$ & $13.4 \pm 0.9$ & $15.5 \pm 0.9$ & $32.4 \pm 2.1$ & $0.3 \pm 0.0$ \\
\hline & & 2014 & $29.8 \pm 0.7$ & $15.5 \pm 0.5$ & $13.6 \pm 0.5$ & $38.3 \pm 4.4$ & $0.9 \pm 0.0$ \\
\hline \multirow{2}{*}{ Esteio } & \multirow{2}{*}{ Automatic } & 2013 & $\mathrm{~m} / \mathrm{d}$ & $3.6 \pm 0.2$ & $25.2 \pm 1.6$ & $20.3 \pm 1.2$ & $0.4 \pm 0.0$ \\
\hline & & 2014 & $\mathrm{~m} / \mathrm{d}$ & $5.4 \pm 0.5$ & $19.9 \pm 0.5$ & $19.3 \pm 3.0$ & $0.4 \pm 0.0$ \\
\hline \multirow{2}{*}{$\begin{array}{l}\text { Santo Antônio } \\
\text { da Patrulha }\end{array}$} & \multirow{2}{*}{$\begin{array}{c}\text { Semi- } \\
\text { automatic }\end{array}$} & 2013 & $19.6 \pm 11.8$ & $6.9 * *$ & $\mathrm{~m} / \mathrm{d}$ & $\mathrm{m} / \mathrm{d}$ & $\mathrm{m} / \mathrm{d}$ \\
\hline & & 2014 & $\mathrm{~m} / \mathrm{d}$ & $\mathrm{m} / \mathrm{d}$ & $\mathrm{m} / \mathrm{d}$ & $\mathrm{m} / \mathrm{d}$ & $\mathrm{m} / \mathrm{d}$ \\
\hline $\begin{array}{c}\text { CONAMA } \\
(1990)\end{array}$ & & & 50.0 & 40.0 & 100.0 & $\begin{array}{l}160.0 \text { (one- } \\
\text { hour mean) }\end{array}$ & $\begin{array}{l}35.0 \text { (one- } \\
\text { hour mean) }\end{array}$ \\
\hline $\begin{array}{c}\text { WHO } \\
(1999 / 2006)\end{array}$ & & & 20.0 & $\begin{array}{l}20.0 \text { (daily } \\
\text { mean) }\end{array}$ & 40.0 & $\begin{array}{l}100.0 \text { (eight- } \\
\text { hour mean) }\end{array}$ & $\begin{array}{l}9.0 \text { (eight- } \\
\text { hour mean) }\end{array}$ \\
\hline
\end{tabular}

*Air quality standards (annual means, except when mentioned differently) according to the Brazilian legislation (CONAMA 1990) and the World Health Organization guidelines (WHO 1999, 2006). **Only one month available. Abbreviation: $\mathrm{m} / \mathrm{d}=\mathrm{missing}$ data. Values shown are the mean of the three exposure periods (two, five and seven months after exposure) and the standard deviations of the same data.

(SA). $\mathrm{NO}_{\mathrm{x}}$ also appeared in higher values in ES and $\mathrm{CH}$ (Figure 4). We observed greater values of ozone in $\mathrm{CH}$ in both years when compared to Esteio (ES), while carbon monoxide did not show any difference.

\section{MAIN POLLUTION COMPOSITION IN EACH CITY}

Cities were grouped based on pollution characteristics through a principal component analysis (Figure 4). Axis 1 explained $43.4 \%$ of the observed variance and axis 2, 28.8\%. Caraá (CA) was more related to higher contents of chromium, while Charqueadas $(\mathrm{CH})$, is closely related to many different metals. A greater relation of $\mathrm{Mn}, \mathrm{Cu}$ and modeled $\mathrm{NO}_{\mathrm{X}}$ and $\mathrm{PM}_{2.5}$ was found in Esteio (ES). Zn was more important in Triunfo (TR) and Montenegro (MO).

\section{DISCUSSION}

The present study provides a description of the atmosphere quality at sites with industrial and rural influences. Further, it consists of a pioneer study on air pollution biomonitoring with lichens in most of the sampled cities, showing relevant concentrations of some air pollutants with negative impact on public health and environmental quality.

\section{PHYSIOLOGICAL RESPONSES}

The effect of exposure to pollutants on Parmotrema tinctorum was visible in most of the thalli. The overall pattern was an increase in the physiology parameters, with the exception of the percentages of live algal cells. Distinctively, the sites of Montenegro and Maquiné had the highest 


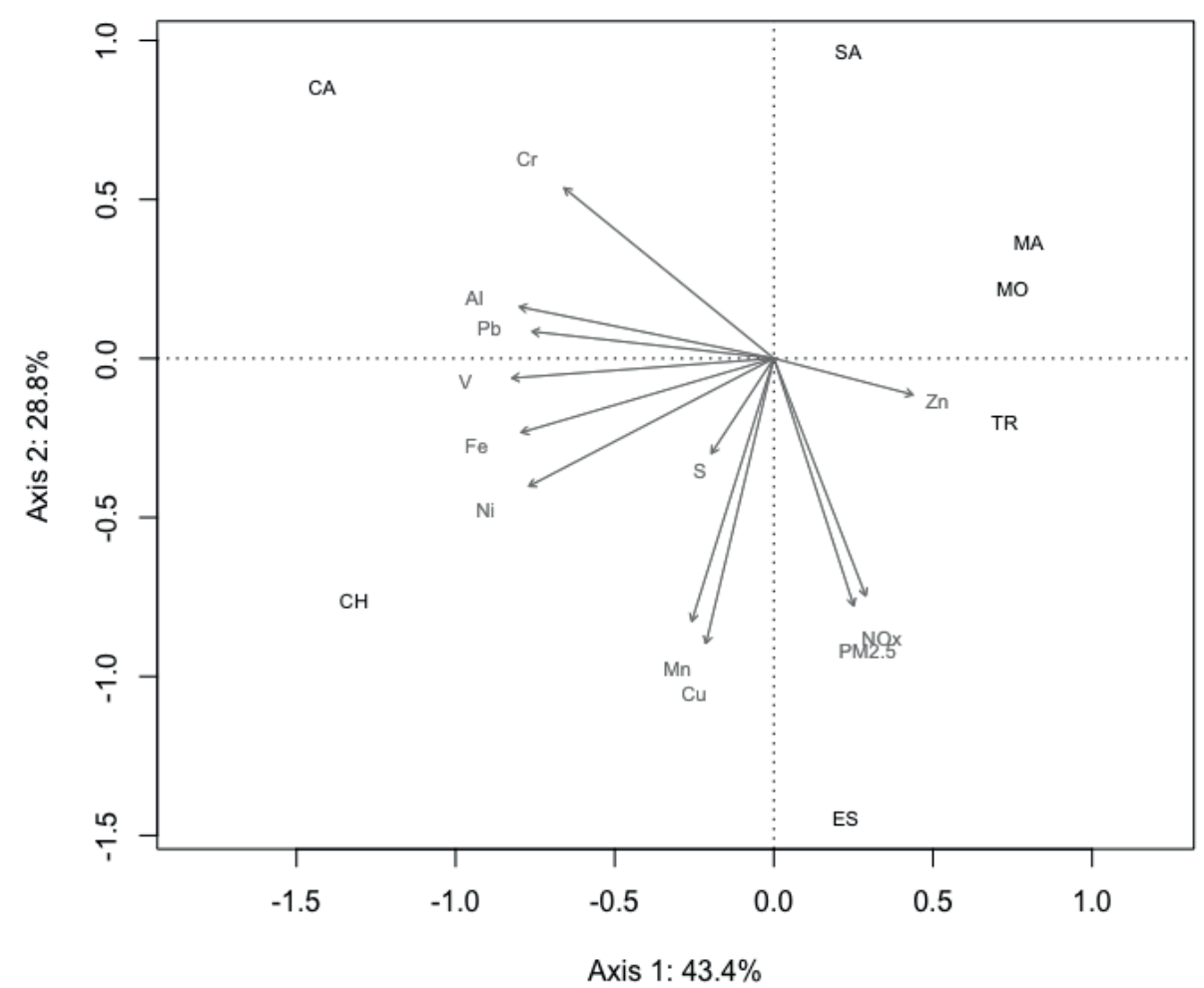

Figure 4 - Diagram of ordination of a PCA (Principal Component Analysis) based on a matrix of sites (cities) described by the pollution variables. Sites are the black letters and the variables, the grey ones. Abbreviations: $\mathrm{CA}=$ Caraá, $\mathrm{CH}=$ Charqueadas, $\mathrm{TR}=$ Triunfo, $\mathrm{MO}=$ Montenegro, $\mathrm{MA}=$ Maquiné, $\mathrm{SA}=$ Santo Antônio da Patrulha, $\mathrm{ES}=$ Esteio, $\mathrm{Cr}=$ Cromium, $\mathrm{Al}=$ Aluminum, $\mathrm{Pb}=$ Lead, $\mathrm{V}=$ Vanadium, $\mathrm{Fe}=$ Iron, $\mathrm{Ni}=$ Nickel, $\mathrm{S}=$ Sulphur, $\mathrm{Mn}=$ Manganese, $\mathrm{Cu}=$ Copper, $\mathrm{PM} 2.5=\mathrm{PM}_{2.5}, \mathrm{NOx}=\mathrm{NO}_{\mathrm{x}}$.

percentages of live algal cells after the exposure period, while Triunfo had the lowest values. It is also noteworthy that Triunfo had higher values of dead and plasmolysed algal cells. While some works have noted that the percentage of dead algal cells is related to air pollution (Calvelo and Liberatore 2004, Käffer et al. 2012), here we show that live algal cells can also be a useful parameter.

Many authors have demonstrated that lichens are highly sensitive to contents of particulate matter, PAHs (Polycyclic Aromatic Carbons), $\mathrm{NO}_{2}$ and $\mathrm{SO}_{2}$, showing physiological damages when exposed to these pollutants (van Herk et al. 2003, Riddell et al. 2012, Käffer et al. 2012). We did not evaluate organic compounds, however their presence is likely reflecting in loss of lichen vitality in the industrial cities, namely PAHs, dioxins, furans and others, which tend to bioaccumulate as a result of atmospheric deposition (Augusto et al. 2013). Although we did not measure organic pollution, we hypothesize that important damage on lichen thalli in Triunfo could be due to the effect of these pollutants from the petrochemical complex nearby the study area, since most metal concentrations were not higher than in other industrial areas.

\section{AIR POLLUTION MONITORING}

Almost all the pollutants absorbed by $P$. tinctorum increased after exposure, a pattern also found in other studies (Käffer et al. 2012). Lichens are known to accumulate and retain many heavy metals in quantities that exceed their physiological requirements because they are able to keep metals 
extracellularly as oxalate crystals or turn them into lichen acids (Backor and Loppi 2009).

Zinc contents were higher in sites with industrial activities such as Esteio and Montenegro. Esteio has a high demographic density (2918 inhabitants $/ \mathrm{km}^{2}$, one of the highest in the state of Rio Grande do Sul), which results in an intense daily traffic. According to Minganti et al. (2003) the main potential sources of zinc are indeed industrial emissions and traffic flow. Sulphur peaks were registered at the beginning of 2014 in all sampled sites. These peaks are unlikely to be related to local pollution events, but instead to some global emissions as maybe a volcanic eruption (Thomas and Prata 2011) or another important source.

The observed peak of chromium in the monitored sites of Caraá and Santo Antônio da Patrulha recorded in 2013 could be either related to leather waste burning in any of the small shoe factories in these cities or could have been released (accidentally or not) by some metalworking industry, since it only occurred in one month during the monitored period. In the urban environment of Porto Alegre, the capital and the largest and most populated city of Rio Grande do Sul, Käffer et al. (2012) found $19.0 \mathrm{mg} / \mathrm{kg}$ as the mean highest concentration of chromium in P. tinctorum, while in our study that amount was more than three times higher (Caraá $=73.0 \mathrm{mg} / \mathrm{kg})$. Charqueadas also had higher contents of chromium (averaging 17.4 $\mathrm{mg} / \mathrm{kg}$ ), but constant throughout the monitoring period. In Europe, a review of chromium averages in mosses between 1990 and 2000 showed that no country had higher concentrations than $8.5 \mathrm{mg} / \mathrm{kg}$ during this period and the trend expected for the next years was a reduction in chromium emissions (Harmens et al. 2007).

Despite only having data for $\mathrm{PM}_{10}, \mathrm{SO}_{2}, \mathrm{NO}_{2}$, $\mathrm{O}_{3}$ and $\mathrm{CO}$ at some sites, this information was valuable to understand the differences among them. It is important to note that all these pollutants were below the levels required by the National Patterns of Air Quality (CONAMA 1990). However, if we consider the guidelines of the World Health Organization for particulate matter $\left(\mathrm{PM}_{10}\right)$, Charqueadas exceeded the suggested limit for health security, which is an annual mean of $20 \mu \mathrm{g} /$ $\mathrm{m}^{3}$ (WHO 2006) and Santo Antônio da Patrulha is also very close to reaching the limit. Charqueadas has a greater demographic density and more intense industrial activity, while Santo Antônio da Patrulha has not many industries, but lately has had a large increment in motor vehicles ( $82 \%$ increase in seven years) (Silva et al. 2015).

Particulate matter may include a wide range of chemical substances, such as elemental and organic carbon compounds; oxides of silicon, aluminum and iron; trace-metals; sulfates; nitrates and ammonia (Bergamaschi et al. 2007). The great danger of high values of $\mathrm{PM}_{10}$ is due to its association to increased rates of bronchitis, reduced lung functions (WHO 2000), and also an increase of cancer risk, since many compounds of the particulate matter are also mutagenic (Coronas et al. 2008, 2009).

In a recent study, Coronas et al. (2008) analyzed the mutagenic activity of airborne particulate material $\left(\mathrm{PM}_{10}\right)$ in Triunfo through the Salmonellal microsome assay, and found positive genotoxic activity, which they related to the presence of PAHs (Polycyclic Aromatic Hydrocarbons). The concentration of $\mathrm{PM}_{10}$ found by this study in 2008 was even higher than was registered here (up to $100 \mu \mathrm{g} / \mathrm{m}^{3}$ ). In Esteio, Coronas et al. (2009) found mutagenic activity in all samples of particulate matter $\left(\mathrm{PM}_{10}\right)$, using the same method. Similar results were found by Pereira et al. (2013) for Montenegro and Santo Antônio da Patrulha. In the latter city, Silva et al. (2015) recorded peaks of 64 $\mu \mathrm{g} / \mathrm{m}^{3}$ of $\mathrm{PM}_{2.5}$, much higher than the limit defined by WHO $\left(25 \mu \mathrm{g} / \mathrm{m}^{3}\right.$ for this parameter), as well as high values of PAHs.

Almost all other greenhouse gases differed among sites, with the exception of Carbon Monoxide. This gas is highly related to vehicular 
emissions (Mayer 1999) and has been controlled by the Brazilian government directly at car industries, through several actions. Since 2003, when this program started, two thirds of emissions have been reduced in the country (IBAMA 2014). As we have observed in this study, it is indeed true that emissions of $\mathrm{CO}$ are controlled, since their concentrations did not change between sites and are much lower than the WHO recommendations (WHO 1999).

As for the other gases, high contents were found in Charqueadas $\left(\mathrm{SO}_{2}\right.$ and $\left.\mathrm{O}_{3}\right)$ and Esteio $\left(\mathrm{NO}_{2}\right)$, which is comparable to the results found through modeled data of $\mathrm{NO}_{\mathrm{x}}$. The higher concentration of $\mathrm{SO}_{2}$ in Charqueadas might be due to the coalfueled power plant, a well-known source of $\mathrm{SO}_{2}$, heavy metals and other elements (Garty 2000). The higher concentration of ozone could be a result of pollutants coming from elsewhere, since this greenhouse gas arises from the oxidation of nitrogen oxides, carbon monoxides and/or volatile organic compounds (Jenkin and Clemitshaw 2000). Nitrogen dioxide $\left(\mathrm{NO}_{2}\right)$, which had the highest values in Esteio, derives mainly from the burning of fossil fuels, and so it is closely related to motor vehicle traffic (Mayer 1999). Esteio has indeed one of the highest demographic densities in our study (2918 inhabitants $/ \mathrm{km}^{2}$ ), almost eighteen times the density of Charqueadas (163 inhabitants $/ \mathrm{km}^{2}$ ) (IBGE 2014).

\section{MAIN POLLUTION COMPOSITION IN EACH CITY}

We created an air pollution profile for the seven monitored cities using data for metals, sulphur, modeled $\mathrm{PM}_{2.5}$ and $\mathrm{NO}_{\mathrm{x}}$ concentrations. It showed the most polluted sites to be Charqueadas and Esteio, with high contents of many pollutants as already discussed. The former has a thermoelectric power plant; the latter, important petrochemical industries; in both cities there are large steel manufacturing industries. These, together with other kinds of industries and also traffic emissions, are probably the main air pollution sources in these cities, which had also high concentrations of gases $\left(\mathrm{SO}_{2}, \mathrm{NO}_{2}\right.$ and $\left.\mathrm{O}_{3}\right)$ and $\mathrm{PM}_{10}$.

The cities of Triunfo and Montenegro, mainly industrial, also accounted for the observed air pollution. Triunfo holds a large Petrochemical Complex, while Montenegro is situated at the main direction of winds coming from this complex. However, organic compounds that were not evaluated would probably better separate these sites from the rural ones (SA, MA and CA). Caraá (CA) seemed to be highly influenced by the great peak of chromium in 2013, while Santo Antônio da Patrulha (SA) and Maquiné (MA) were characterized by lower concentrations of the analyzed pollutants.

\section{CONCLUSIONS}

As lichens are one of the most valuable biomonitors of atmospheric pollution and monitoring this pollution is extremely important for public and environmental health, this study contributes to the knowledge of the air quality in southern Brazil.

Based on the profile of air pollution we generated for the sites we could point out that Charqueadas and Esteio had the worst air quality in the region. Since both cities have high demographic densities, these results are of great public health concern. Moreover, it is important to highlight that air pollution is not limited to dense populated and industrial cities. We showed here that even apparently unpolluted sites, such as small rural cities with family farming as the main economic activity, could be affected by external (or internal) sources of pollutants.

Although it is still hard to determine the exact sources of elements reaching the lichen thalli, the knowledge on the distribution patterns of these pollutants is indeed of high value for society and for decision making such as where to direct attention to health or where the air quality is already 
too saturated. Thus, this study could be a tool for environmental health protection and a guideline for future studies.

\section{ACKNOWLEDGMENTS}

Authors would like to thank the Graduate Program in Ecology from Universidade Federal do Rio Grande do Sul (UFRGS) for all assistance during this work, to Coordenação de Aperfeiçoamento de Pessoal de Nível Superior (CAPES) for the first author's $\mathrm{PhD}$ financial support, to Fundação Estadual de Proteção Ambiental Henrique Luiz Roessler (FEPAM/RS) for providing the access to their pollution monitoring data, to Marcelo Alonso from Universidade Federal de Pelotas (UFPel) for providing the modeled pollutants information, to Fundação Zoobotânica RS (FZB/RS) for helping with logistics and lab structure. We are grateful to all the cities and their city halls mentioned in the text and to Fundação Estadual de Pesquisa Agropecuária (Fepagro) Litoral Norte for sampling permissions. We also thank Laura Cappelatti from Swansea University for English writing revision. The first author currently has a PNPD (National Program for Post-Doctoral) sponsorship from CAPES.

\section{REFERENCES}

AKIMOTO H. 2003. Global air quality and pollution. Science 302: 1716-1719.

ALVES ES, GIUSTI PM, DOMINGOS M, SALDIVA PHN, GUIMARÃES ET AND LOBO DJA. 2001. Estudo anatômico foliar do clone híbrido 4430 de Tradescantia: alterações decorrentes da poluição aérea urbana. Rev Bras Bot 24(4): 567-576.

APHA - AMERICAN PUBLIC HEALTH ASSOCIATION. 2005. Standard Methods for the examination of water and wastewater. Washington, DC: American Public Health Association.

ARAS S, BEYAZTAS T, CANSARAN-DUMA D AND GÖKCE-GÜNDÜZER E. 2011. Evaluation of genotoxicity of Pseudevernia furfuracea (L.) Zopf. by RAPD analysis. Genet Mol Res 10: 1-11.

AUGUSTO S, MÁGUAS C AND BRANQUINHO C. 2013. Guidelines for biomonitoring persistent organic pollutants
(POPs), using lichens and aquatic mosses - A review. Environ Pollut 180: 330-338.

BACKOR M AND LOPPI S. 2009. Interactions of lichens with heavy metals. Biol Plantarum 53(2): 214-222.

BERGAMASCHI L, RIZZIO E, GIAVERI G, LOPPI S AND GALLORINI M. 2007. Comparison between the accumulation capacity of four lichen species transplanted to an urban site. Environ Pollut 148(2): 468-476.

BIGNAL KL, ASHMORE MK AND HEADLEY AD. 2008. Effects of air pollution from road transport on growth and physiology of six transplanted bryophyte species. Environ Pollut 156 (2): 332-340.

BOONPRAGOB K. 2002. Monitoring physiological change in lichens: total chlorophyll content and chlorophyll degradation. In: Nimis PL, Scheidegger C and Wolseley PA (Eds), Monitoring with Lichens, Dordrecht, Kluwer Academic Publisher, p. 323-326.

BOSS CB AND FREDEEN KJ. 2004. Concepts, Instrumentation and Techniques in Inductively Coupled Plasma Optical Emission Spectrometry. Shelton, Perkin Elmer.

CALVELO S AND LIBERATORE S. 2004. Applicability of in situ or transplanted lichens for assessment of atmospheric pollution in Patagonia, Argentina. J Atmos Chem 49: 199210.

CANSARAN-DUMAN D, ATAKOL O AND ARAS S. 2010 Assesment of air pollution genotoxicity by RAPD in Evernia prunastri L. Ach. From around iron-steel factory in Karabük, Turkey. J Environ Sci 23: 1171-1178.

CARRERAS HA AND PIGNATA ML. 2002. Biomonitoring of heavy metals and air quality in Cordoba City, Argentina, using transplanted lichens. Environ Pollut 117: 77-87.

CONAMA - CONSELHO NACIONAL DE MEIO AMBIENTE. 1990. Resolução CONAMA no. 003, de 28 de junho de 1990. Padrões Nacionais de Qualidade do Ar, Brasília, Conselho Nacional do Meio Ambiente, IBAMA, p. 199-205.

CONTI ME AND CECCHETTI G. 2001. Biological monitoring: lichens as bioindicators of air pollution assessment - a review. Environ Pollut 114: 471-492.

CORONAS MV, HORN RC, DUCATTI A, ROCHA JV AND VARGAS VMF. 2008. Mutagenic activity of airborne particulate matter in a petrochemical industrial area. Mutat Res 650(2): 196-201.

CORONAS MZ, PEREIRA TS, ROCHA JAV, LEMOS AT, FACHEL JMG, SALVADORI DMF AND VARGAS VMF. 2009. Genetic biomonitoring of an urban population exposed to mutagenic airborne pollutants. Environ Int 35(7): 1023-1029.

CRITTENDEN PD AND READ DJ. 1979. The effects of air pollution on plant growth with special reference to sulphur dioxide. III. Growth studies with Lolium multiflorum Lam. and Dactylis glomerata L. New Phytol 83: 645-651. 
DOMINGOS M, BULBOVAS P, CAMARGO CZS, AGUIARSILVA C, BRANDÃO SE, DAFRÉ-MARTINELLI M, DIAS APL, ENGELA MRGS AND GAGLIANO J. 2015. Searching for native tree species and respective potential biomarkers for future assessment of pollution effects on the highly diverse Atlantic Forest in SE-Brazil. Environ Pollut 202: 85-95.

FREITAS SR ET AL. 2009. The Coupled Aerosol and Tracer Transport model to the Brazilian developments on the Regional Atmospheric Modeling System (CATT-BRAMS) - Part 1: Model description and evaluation. Atmos Chem Phys 9: 2843-2861.

GARTY J. 2000. Environment and elemental contents of lichens. In Markert B and Friese K (Eds), Trace-elements - Their distribution and effects in the environment, Amsterdam, Elsevier, p. 245-276.

GERDOL R, MARCHESINI R, IACUMIN P AND BRANCALEONI L. 2014. Monitoring temporal trends of air pollution in an urban area using mosses and lichens as biomonitors. Chemosphere 108: 388-395.

HARMENS H, NORRIS DA, KOERBER GR, BUSE A, STEINNES E AND RÜHLING A. 2007. Temporal trends in the concentration of arsenic, chromium, copper, iron, nickel, vanadium and zinc in mosses across Europe between 1990 and 2000. Atmos Environ 41: 6673-6687.

HAWKSWORTH DL, ITURRIAGA T AND CRESPO A. 2005. Líquenes como bioindicadores inmediatos de contaminación y cambios medio-ambientales en los trópicos. Rev Iberoam Micol 22: 71-82.

IBAMA - INSTITUTO BRASILEIRO DO MEIO AMBIENTE E DOS RECURSOS NATURAIS RENOVÁVEIS. 2014. Inventário Nacional de Emissões Atmosféricas por Veículos Automotores Rodoviários, Relatório Final, Anobase 2012. http://www.ibama.gov.br/areas-tematicasqa/programa-proconve. Accessed 8 December 2014.

IBGE - INSTITUTO BRASILEIRO DE GEOGRAFIA E ESTATÍSTICA. 2014. Perfil dos Estados e Municípios Brasileiros 2014.

http://www.ibge.gov.br/home/estatistica/economia/ perfilmunic/2014/. Assessed 10 January 2016.

JENKIN ME AND CLEMITSHAW KC. 2000. Ozone and other secondary photochemical pollutants: chemical processes governing their formation in the planetary boundary layer. Atmos Environ 34: 2499-2527.

KÄFFER MI, LEMOS AT, APEL MA, ROCHA JV, MARTINS SMA AND VARGAS VMF. 2012. Use of bioindicators to evaluate air quality and genotoxic compounds in an urban environment in Southern Brazil. Environ Pollut 163: 2431.

KOCH NM, BRANQUINHO C, MATOS P, PINHO P, LUCHETA F, MARTINS SMA AND VARGAS VMF. 2016. Functional diversity and traits assembly patterns of lichens as indicators of successional stages in a tropical rainforest. Environ Sci Pollut R 23: 20819-20834.

LE BLANC FSC. 1971. Possibilities and methods for mapping air pollution on the basis of lichen sensitivity. Mitteilungen aus der Forstlichen Bundesversuchsantalt 92: 103-126.

LONGO KM ET AL. 2013. The Chemistry CATT-BRAMS model (CCATT-BRAMS 4.5): a regional atmospheric model system for integrated air quality and weather forecasting and research. Geosci Model Dev 6: 13891405.

LOPPI S AND FRATI L. 2006. Lichen diversity and lichen transplants as monitors of air pollution in a rural area of Central Italy. Environ Monit Assess 114: 361-375. MAYER H. 1999. Air pollution in cities. Atmos Environ 33: 4029-4037.

MINGANTI V, CAPELLI R, DRAVA G, PELLEGRINI R, BRUNIALTI G, GIORDANI P AND MODENESI P. 2003. Biomonitoring of trace metals by different species of lichens (Parmelia) in North-West Italy. J Atmos Chem 45: 219-229.

NASH III T. 2008. Lichen sensitivity to air pollution. In Nash III T (Ed), Lichen Biology, $2^{\text {nd }}$ ed., Cambridge, Cambridge.

PACHAURI RK, ALLEN MR AND BARROS VR. 2014. Climate Change 2014, IPCC Fifth Assessment Synthesis Report. http://www.ipcc.ch. Assessed 7 December 2014.

PEEL MC, FINLAYSON BL AND MCMAHON TA. 2007. Updated world map of the Köppen-Geiger climate classification. Hydrol Earth Sys Sc 11: 1633-1644.

PEREIRA TS, BELTRAMI LS, ROCHA JAV, BROTO FP, COMELLAS LR, SALVADORI DMF AND VARGAS VMF. 2013. Toxicogenetic monitoring in urban cities exposed to different airborne contaminants. Ecotox Environ Safe 90: 174-182.

PINHO P, DIAS T, CRUZ C, TANG YS, SUTTON MA, LOUÇÃO MAM, MÁGUAS C AND BRANQUINHO C. 2011. Using lichen functional diversity to assess the effects of atmospheric ammonia in Mediterranean woodlands. J Appl Ecol 48: 1107-1116.

R CORE TEAM 2015. R: A Language and Environment for Statistical Computing. Vienna: R Foundation for Statistical Computing.

RIDDELL J, PADGET PE AND NASH III TH. 2012. Physiological responses of lichens to factorial fumigations with nitric acid and ozone. Environ Pollut 170: 202-210.

SANDRIN CZ, FIGUEIREDO-RIBEIRO RCL, DELITTI WBC AND DOMINGOS M. 2013. Short-term changes of fructans in ryegrass (Lolium multiflorum 'Lema') in response to urban air pollutants and meteorological conditions. Ecotox Environ Safe 96: 80-85.

SILVA CS, ROSSATO JM, ROCHA JAV AND VARGAS VMF. 2015. Characterization of an area of reference for inhalable particulate matter $\left(\mathrm{PM}_{2.5}\right)$ associated with genetic biomonitoring in children. Mutat Res 778: 44-55. 
SPIELMANN AA AND MARCELLI MP. 2009. Parmotrema s.l. (Parmeliaceae, lichenized Ascomycota) from Serra Geral slopes in central Rio Grande do Sul State, Brazil. Hoehnea 36(4): 551-595.

SZCZEPANIAK K AND BIZIUK M. 2003. Aspects of the biomonitoring studies using mosses and lichens as indicators of metal pollution. Environ Res 93 (3): 221-230.

THOMAS HE AND PRATA AJ. 2011. Sulphur dioxide as a volcanic ash proxy during the April-May 2010 eruption of Eyjafjallajokull Volcano, Iceland. Atmos Chem Phys 11: 7757-7780.

VAN HERK CM, MATHIJSSEN-SPIEKMAN EAM AND DE ZWART D. 2003. Long distance nitrogen air pollution effects on lichens in Europe. Lichenologist 35(4): 347-359.
WHO - WORLD HEALTH ORGANIZATION. 1999. Environmental criteria 213: Carbon monoxid, $2^{\text {nd }}$ ed., Geneva: World Health Organization.

WHO - WORLD HEALTH ORGANIZATION. 2000. Air quality guidelines for Europe (second edition). Copenhagen: World Health Organization.

WHO - WORLD HEALTH ORGANIZATION. 2006. Air quality guidelines for particulate matter, ozone, nitrogen, dioxide and sulphur dioxide - Global update 2005. Copenhagen: World Health Organization.

WHO - WORLD HEALTH ORGANIZATION. 2017. Inheriting a sustainable world? Atlas on children's health and the environment. Geneva: World Health Organization. 